\title{
Programa de Cuidados Especiais ao Óbito
}

\author{
Siqueira, Meire do Caemo; Cotrim, Ana Moreira; Noia, Ruth Vivaldo; Rodriguez, \\ Lórgio Henrique Dias; Afonso, Carmem Andréa
}

Instituto do Câncer do Estado de São Paulo - meiresique@bol.com.br

Introdução a morte representa, em nossa cultura, uma dor emocional intensa, um sofrimento que geralmente causa descontrole emocional diante da separação e significado de derrota frente à doença. a família, geralmente, cultiva o sentimento de esperança durante todo o tratamento, sentindo-se revoltada e indignada por não aceitar a evolução e o processo de finitude de seu ente querido, abalando internamente a estrutura familiar. o Programa surgiu frente à necessidade dos familiares e pacientes descompensados emocionalmente, sem conseguir manter o controle emocional e, portanto, sem condições psíquicas para receberem as orientações formais; além da demanda de casos graves que geram um fluxo intenso de perdas e lutos vividos na Instituição. Entretanto, para que o programa possa cumprir-se em sua plenitude, contamos com a equipe multiprofissional: equipe médica, de enfermagem e o serviço social. Juntos com o Serviço de Psicologia Hospitalar, oferecemos aos pacientes e familiares, acolhimento, segurança e conforto em um momento de desorganização emocional e psicológica. Objetivos Proporcionar suporte emocional, afetivo e psíquico em situações de crise, frente ao fechamento do ciclo da doença, minimizando manifestações psíquicas e comportamentais que possam mobilizar dificuldades durante o processo de luto, tais como: ansiedade, angústia, insegurança, negação, hostilidade, desamparo, estresse psico-orgânico, medos reais e fantasmáticos, entre outras. Auxiliar familiares e oferecer suporte para elaboração do luto antecipatório, garantindo informações seguras durante o processo de adoecimento, esclarecendo dúvidas e fornecendo informações atuais sobre a doença, para que pacientes e familiares possam se organizar social e emocionalmente. É realizado atendimento individual ou em grupo com a equipe multi do aviso de grave ao óbito, promovendo suporte psicológico e orientações formais sobre sepultamento, translado do corpo, documentação e outras dúvidas por meio do Serviço Social. Métodos Através do atendimento psicológico imediato e eficiente da psicoterapia breve, em modelo de ligação, oferecemos suporte emocional e orientação psicológica aos pacientes e familiares, visando minimizar o sofrimento psíquico causado pelo processo de adoecimento, tratamento e terminalidade. Contando com a equipe multiprofissional, promovemos humanização e excelência nos atendimentos em pré e pós-óbitos, favorecendo a relação: equipe de saúde paciente família instituição. Resultados: em 2013 ocorreram 2.286 óbitos na Instituição, com média mensal de 190 óbitos, nesses, 3.561 atendimentos foram realizados pela equipe de psicologia, em certos casos a família foi acolhida mais de uma vez no Programa de Cuidados Especiais ao Óbito. Conclusão: o Programa propõe garantir tratamento humanizado, acolhimento e apoio aos familiares e pacientes em todo o processo de finitude, minimizando em todos os aspectos a dor da "partida".

Siqueira, Meire do Caemo; Cotrim, Ana Moreira; Noia, Ruth Vivaldo; Rodriguez, Lórgio Henrique Dias; Afonso, Carmem Andréa. Programa de Cuidados Especiais ao Óbito. In: Anais do Congresso Internacional de Humanidades \& Humanização em Saúde [= Blucher Medical Proceedings, num.2, vol.1]. São Paulo: Editora Blucher, 2014. ISSN 2357-7282

DOI 10.5151/medpro-cihhs-10785 